\title{
Immunochemical Analysis of Antigenic Determinants of Chlamydia trachomatis by Monoclonal Antibodies
}

\author{
By MARJA-TERTTU MATIKAINEN* AND PERTTI TERHO \\ Department of Virology, University of Turku, Kiinamyllynkatu 13, 20520 Turku 52, Finland
}

(Received 26 October 1982; revised 9 March 1983)

\begin{abstract}
Monoclonal antibodies to outer membrane of Chlamydia trachomatis lymphogranuloma venereum (LGV) strain L1 (440-L) were used for antigen characterization. Two separate typespecific antigenic determinants (epitopes) and one species-specific epitope were represented in the major outer-membrane protein (MOMP, molecular weight 40000) of homologous (440-L) and heterologous (IOL-1962, 810-B) L1 strains. One of the type-specific antibodies, the reactivity of which was not affected by oxidation or reduction of the antigenic sites, partially prevented the binding of species-specific antibody as determined by solid-phase radioimmunoassay. The binding of type- and species-specific antibody could be destroyed with proteolytic enzyme treatment. The reactivity of genus-specific monoclonal antibody originating from another fusion $(\mathrm{L} 2,434-\mathrm{Bu})$ was unaffected by proteolytic treatment but was sensitive to periodate, indicating the carbohydrate nature of the genus-specific epitope. Heating of antigens had no effect on the affinity of monoclonal antibodies studied.
\end{abstract}

\section{INTRODUCTION}

Chlamydia trachomatis, a prokaryotic parasite of eukaryotic cells, is an important human pathogen. Mechanisms of chlamydial infection, like phagocytosis and the intracellular developmental cycle, are determined at least partially by surface antigenic properties of the chlamydial elementary body (EB) (Schachter \& Caldwell, 1980). The outer membrane of EB morphologically resembles that of Gram-negative bacteria (Caldwell et al., 1981). The major outermembrane protein (MOMP) is the principal constituent of the rigid chlamydial outer layer. The molecular weight of MOMP varies, depending on the strain (Salari \& Ward, 1981).

Different strains have on their outer membrane, type-specific epitopes, which are the basis for classifying $C$. trachomatis into 15 immunotypes by the microimmunofluorescence test (microIF) (Wang \& Grayston, 1982). The genus-specific reactivity common to $C$. trachomatis and $C$. psittaci has been found to be mediated by a carbohydrate antigen containing 2-keto-3deoxyoctanoic acid (Dhir et al., 1972). A genus-specific antigen is located just beneath the outer membrane (Dhir \& Boatman, 1972).

Stephens et al. (1982) found chlamydial species- and subspecies-specific antigenic determinants in MOMP by using monoclonal antibodies. The current study has utilized monoclonal antibodies to investigate the distribution of type- and species-specific epitopes present on MOMP of lymphogranuloma venereum (LGV) L1 strains. The protein nature of these epitopes was confirmed by proteolytic enzyme treatment of EB antigen.

Abbreviations: COMC, chlamydial outer-membrane protein complex; EB, chlamydial elementary bodies; microIF, microimmunofluorescence test; MOMP, major outer-membrane protein; RIA, radioimmunoassay; TBS, Tris-buffered saline. 


\section{METHODS}

Growth and purification of chlamydial antigens. The C. trachomatis LGV strains used were: L1 (440-L), L1 (IOL1962), L1 (810-B), L2 (434-Bu) and L3 (404-B). The trachoma strain B (Tw-5) was used for comparison.

The strains were grown in cycloheximide-treated $\left(1 \mu \mathrm{g} \mathrm{ml}^{-1}\right) \mathrm{McCoy}$ cells and EBs were purified in Renografin (E. R. Squibb \& Sons, Princeton, N.J., U.S.A.) gradients (Terho \& Matikainen, 1981). Chlamydial outermembrane complex (COMC) was isolated with sarkosyl $(2 \%, \mathrm{w} / \mathrm{v})$ after the method of Caldwell et al. (1981).

Production of monoclonal antibodies. Our application of the original method of Köhler \& Milstein (1975) has been described earlier (Terho et al., 1982). Briefly, BALB/c mice were immunized subcutaneously with COMC preparation mixed with Freund's incomplete adjuvant, followed by an intravenous booster dose. Spleen lymphocytes and mouse plasmacytoma cells (NS-I) were fused with polyethylene glycol 4000 supplemented with $5 \%$ (v/v) dimethyl sulphoxide. Hybrids surviving in hypoxanthine-aminopterin-thymidine medium were tested by enzyme immunoassay (ELISA) and reactive hybridomas were cloned by dilution. Hybrids of monoclonal origin were injected intraperitoneally into pristane-primed BALB/c mice and ascitic fluid was collected. Type-specific antibody reactivity was determined by microimmunofluorescence (microIF) (J. Treharne, Institute of Ophthalmology, London) and by radioimmunoassay (RIA) (Terho \& Matikainen, 1981) or ELISA in our laboratory. The subclass of monoclonal antibody was determined by antigen-specific ELISA using rabbit antisera against mouse immunoglobulin subclasses (Miles).

${ }^{125}$ I labelling of monoclonal antibodies. The ascitic fluid was dialysed against phosphate-buffered saline (PBS; $0.01 \mathrm{M}$-phosphate buffer, $0.15 \mathrm{M}-\mathrm{NaCl} \mathrm{pH} 7 \cdot 2$ ) and labelled by the method of Hunter \& Greenwood (1962). The non-bound ${ }^{125}$ I was removed by dialysis against PBS. Finally, one volume of $40 \%(\mathrm{v} / \mathrm{v})$ foetal calf serum, $42 \%(\mathrm{v} / \mathrm{v})$ glycerol, $0 \cdot 2 \%(\mathrm{w} / \mathrm{v}) \mathrm{NaN}_{3}$ in PBS was added to stabilize the labelled immunoglobulins. The specific activities obtained were $6,6.8$ and $7.5 \mu \mathrm{Ci}(\mu \mathrm{g} \text { protein })^{-1}$ for $\mathrm{L} 1 / \mathrm{Al}\left(\mathrm{IgG}_{3}\right), \mathrm{L1} / \mathrm{B} 5 / \mathrm{H} 4(\mathrm{IgM})$ and $\mathrm{L1} / \mathrm{C} 5 / \mathrm{B} 8\left(\mathrm{IgG}_{3}\right)$ antibodies, respectively $(1 \mu \mathrm{Ci}=37 \mathrm{kBq})$. Monoclonal antibody $\mathrm{Ll} / \mathrm{Al}$ lost the avidity for chlamydial L1 typespecific antigen almost completely after ${ }^{125} \mathrm{I}$ labelling.

Specificity analysis of monoclonal antibodies. The polypeptides of intact EB of C. trachomatis strains [L1 (440-L), L2 (434-Bu), L3 (404-B) and B (Tw-5)] as well as McCoy cell lysates were analysed by SDS-PAGE on gels with a linear gradient of 8 to $18.9 \%(\mathrm{w} / \mathrm{v}$ ) acrylamide and having $2.6 \%$ gel cross-linking (Hukkanen, 1982). Each sample $(60 \mu \mathrm{g})$ was dissociated for $3 \mathrm{~min}$ at $100{ }^{\circ} \mathrm{C}$ in $0.1 \mathrm{M}$-Tris $/ \mathrm{HCl} \mathrm{pH} 6.8$ containing $2 \%(\mathrm{w} / \mathrm{v}) \mathrm{SDS}, 5 \%(\mathrm{v} / \mathrm{v})$ $\beta$-mercaptoethanol, $5 \%(\mathrm{v} / \mathrm{v})$ glycerol and $0.005 \%(\mathrm{w} / \mathrm{v})$ bromphenol blue. The samples were electrophoresed for $18 \mathrm{~h}$ at constant current $(8 \mathrm{~mA})$. Coomassie brilliant blue-stained polypeptides are seen in Fig. 1.

After the electrophoresis the polypeptides were transferred on to nitrocellulose sheets $(0.45 \mu \mathrm{m}$ pore size; Millipore) by the 'Western blotting' method of Towbin et al. (1979) using an electrophoretic Gel Destainer (GD-4, Pharmacia) with the nitrocellulose sheet facing the anode. The chamber contained $25 \mathrm{~mm}$-Tris, $192 \mathrm{~mm}$-glycine in $20 \%(\mathrm{v} / \mathrm{v})$ methanol, $\mathrm{pH} 8 \cdot 3$. A voltage of $36 \mathrm{~V}$ was applied for $3 \mathrm{~h}$. The polypeptides on the nitrocellulose sheet were fixed with $6 \mathrm{M}$-urea and stained by heparin-toluidine blue (Vartio et al., 1982). The lanes were cut, destained by $8 \%(\mathrm{v} / \mathrm{v})$ acetic acid, $50 \%(\mathrm{v} / \mathrm{v})$ methanol and finally washed in $0 \cdot 1-\mathrm{M}$-Tris $/ \mathrm{HCl} \mathrm{pH} 7 \cdot 4$ supplemented with $0.9 \%$ (w/v) $\mathrm{NaCl}$ (TBS). Non-specific binding was prevented by overnight incubation with $20 \%(\mathrm{v} / \mathrm{v})$ foetal calf serum in TBS. ${ }^{125}$ I-labelled antibodies in $20 \%(\mathrm{v} / \mathrm{v})$ foetal calf serum-TBS (approx. 10000 c.p.m.; Terho \& Matikainen, 1981) were layered on the strips and incubated for $2 \mathrm{~h}$ at $25^{\circ} \mathrm{C}$. The strips were then carefully washed in TBS, dried and subjected to autoradiography on Kodak RP-Royal X-Omat film.

Epitope analysis by RIA. Polystyrene beads were coated with $\mathrm{Ll}(440-\mathrm{L}) \mathrm{EB}$-antigen (1 $\mu \mathrm{g}$ per bead in PBS) and incubated with type-specific, species-specific or genus-specific monoclonal antibodies. Beads were mixed with ascitic fluid diluted 1 in 200 to $I$ in 204800 in RIA buffer [PBS (pH 7.2) supplemented with $0.5 \%$ (w/v) bovine serum albumin, $0.5 \%(\mathrm{v} / \mathrm{v})$ Tween 20 and $10^{-4} \mathrm{M}$-merthiolate] and incubated at $37^{\circ} \mathrm{C}$ for $2 \mathrm{~h}$. The beads were washed three times with $5 \mathrm{ml}$ washing buffer [PBS supplemented with $0 \cdot 1 \%(\mathrm{v} / \mathrm{v})$ Tween 20] then incubated at $37^{\circ} \mathrm{C}$ for $2 \mathrm{~h}$ with ${ }^{125} \mathrm{I}$-labelled type-specific antibody or species-specific antibody (5000 c.p.m.). The beads were washed three times with washing buffer, transferred to clean tubes and counted in an LKB 1270 Rackgamma counter.

Chemical characterization of epitopes in MOMP. Polystyrene beads coated with intact and sonicated $(2 \cdot 5 \mathrm{~min}$, $20 \mathrm{kHz}, 20 \mathrm{~W}) \mathrm{EB}$ antigen $(1 \mu \mathrm{g}$ per bead) were used as solid-phase. These beads were chemically treated before performing RIA with monoclonal antibodies. The treatments were: (1) heating for $10 \mathrm{~min}$ at $100^{\circ} \mathrm{C},(2)$ oxidation with sodium $m$-periodate $\left(0.05 \mathrm{~m}\right.$; Sigma) for $24 \mathrm{~h}$ at $4{ }^{\circ} \mathrm{C}$, (3) reduction with $\beta$-mercaptoethanol $(5 \%$, v/v; Fluka) for $24 \mathrm{~h}$ at $4{ }^{\circ} \mathrm{C}$, and (4) pronase from Streptomyces griseus $\left(100 \mu \mathrm{g} \mathrm{ml}^{-1}\right.$; Calbiochem), and proteinase $\mathrm{K}$ from Tritrachium album $\left(100 \mu \mathrm{g} \mathrm{ml}{ }^{-1}\right.$; Beckman) for $2 \mathrm{~h}$ at $37^{\circ} \mathrm{C}$.

The treated and control beads were washed as before and incubated at $37^{\circ} \mathrm{C}$ for $2 \mathrm{~h}$ with monoclonal ascitic antibodies diluted 1 in $10^{3}$ to 1 in $10^{7}$ in RIA buffer. The beads were washed with $5 \mathrm{ml}$ washing buffer and then incubated with rabbit anti-mouse $\mathrm{Ig}$ ( 1 in 2000 ; Dako, Denmark) for $1 \mathrm{~h}$ at $37^{\circ} \mathrm{C}$. After washing, the beads were incubated with ${ }^{125} \mathrm{I}$-labelled sheep anti-rabbit $\operatorname{IgG}(5000 \mathrm{c}$.p.m. per bead $)$ at $37^{\circ} \mathrm{C}$ for $1 \mathrm{~h}$. The bound radioactivity was measured. 


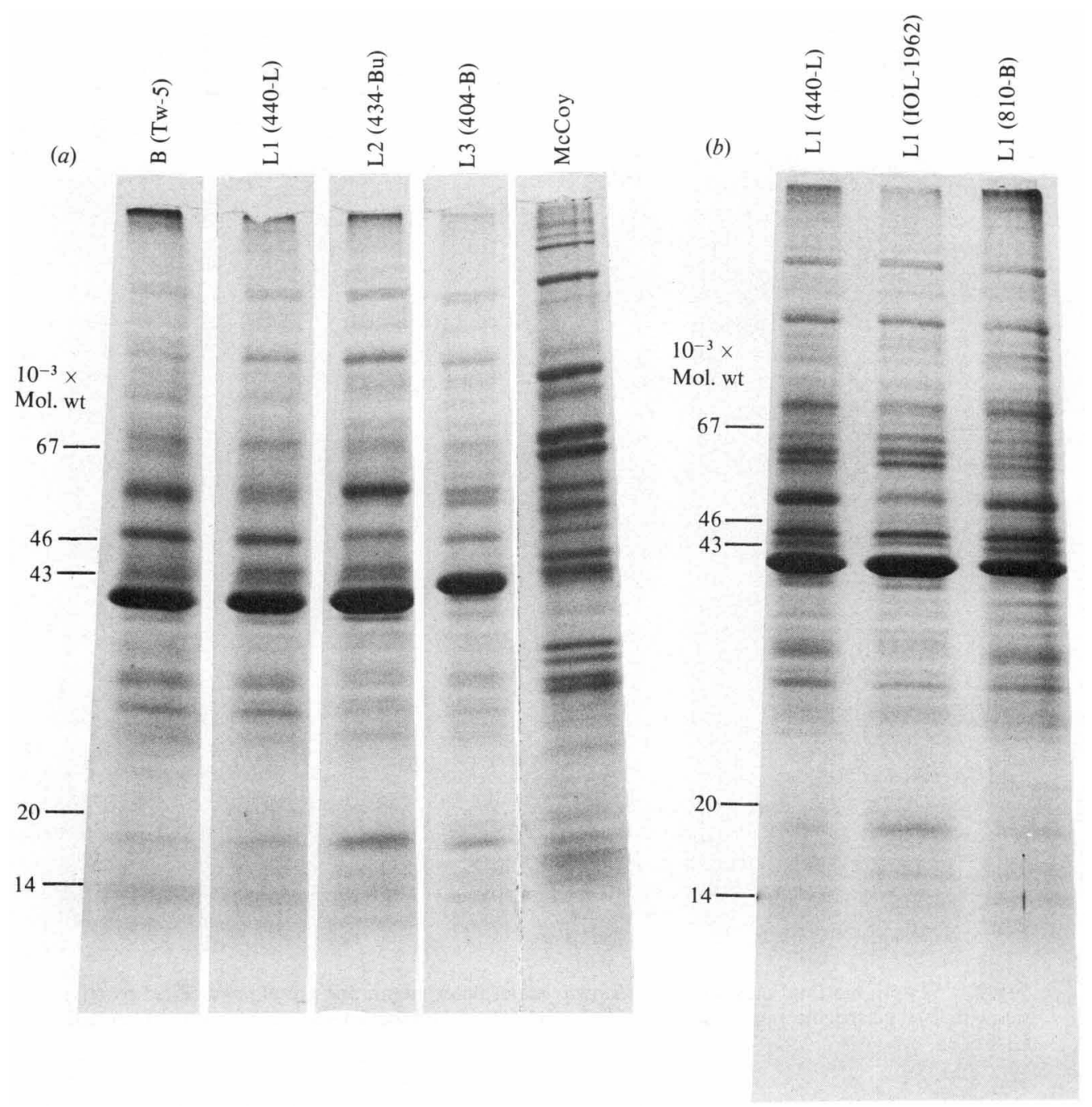

Fig. 1. SDS-PAGE of (a) C. trachomatis B (Tw-5), L1 (440-L), L2 (434-Bu), L3 (404-B) and McCoy, and (b) L1 (440-L), L1 (IOL-1962) and L1 (810-B).

Table 1. Properties of $C$. trachomatis monoclonal antibodies studied

The table shows immunoglobulin subclasses, microIF titres [against $C$. trachomatis immunotypes $\mathrm{A}$ to $\mathrm{K}, \mathrm{L} 1, \mathrm{~L} 2, \mathrm{~L} 3$ and $C$. psittaci (CP)] and specificity.

\begin{tabular}{|c|c|c|c|c|c|c|c|}
\hline \multirow[b]{2}{*}{ Clone } & \multirow[b]{2}{*}{ Ig class } & \multicolumn{5}{|c|}{ MicroIF titres } & \multirow[b]{2}{*}{ Specificity } \\
\hline & & $A-K$ & $\mathrm{~L} 1$ & $\mathrm{~L} 2$ & L3 & $\mathrm{CP}$ & \\
\hline $\mathrm{Ll} / \mathrm{Al}$ & $\operatorname{IgG}_{3}$ & 0 & 2048 & 0 & 0 & 0 & Type-specific \\
\hline $\mathrm{L} 1 / \mathrm{B} 5 / \mathrm{H} 4$ & $\operatorname{IgM}$ & 0 & 2048 & 0 & 0 & 0 & Type-specific \\
\hline $\mathrm{Ll} / \mathrm{C} 5 / \mathrm{B} 8$ & $\mathrm{IgG}_{3}$ & $512-2048$ & 1024 & 2048 & 2048 & 0 & Species-specific \\
\hline $\mathrm{L} 2 / \mathrm{A} 11 / \mathrm{G} 3 / \mathrm{G} 4$ & $\mathrm{IgG}_{3}$ & $\geqslant 128$ & $\geqslant 128$ & $\geqslant 128$ & $\geqslant 128$ & $\geqslant 128$ & Genus-specific \\
\hline
\end{tabular}

Characterization of monoclonal antibodies

The properties of the monoclonal antibodies studied are presented in Table 1. L1/A1 antibody has been described earlier (Terho et al., 1982). Antibodies L1/A1 and L1/B5/H4 are L1 type- 

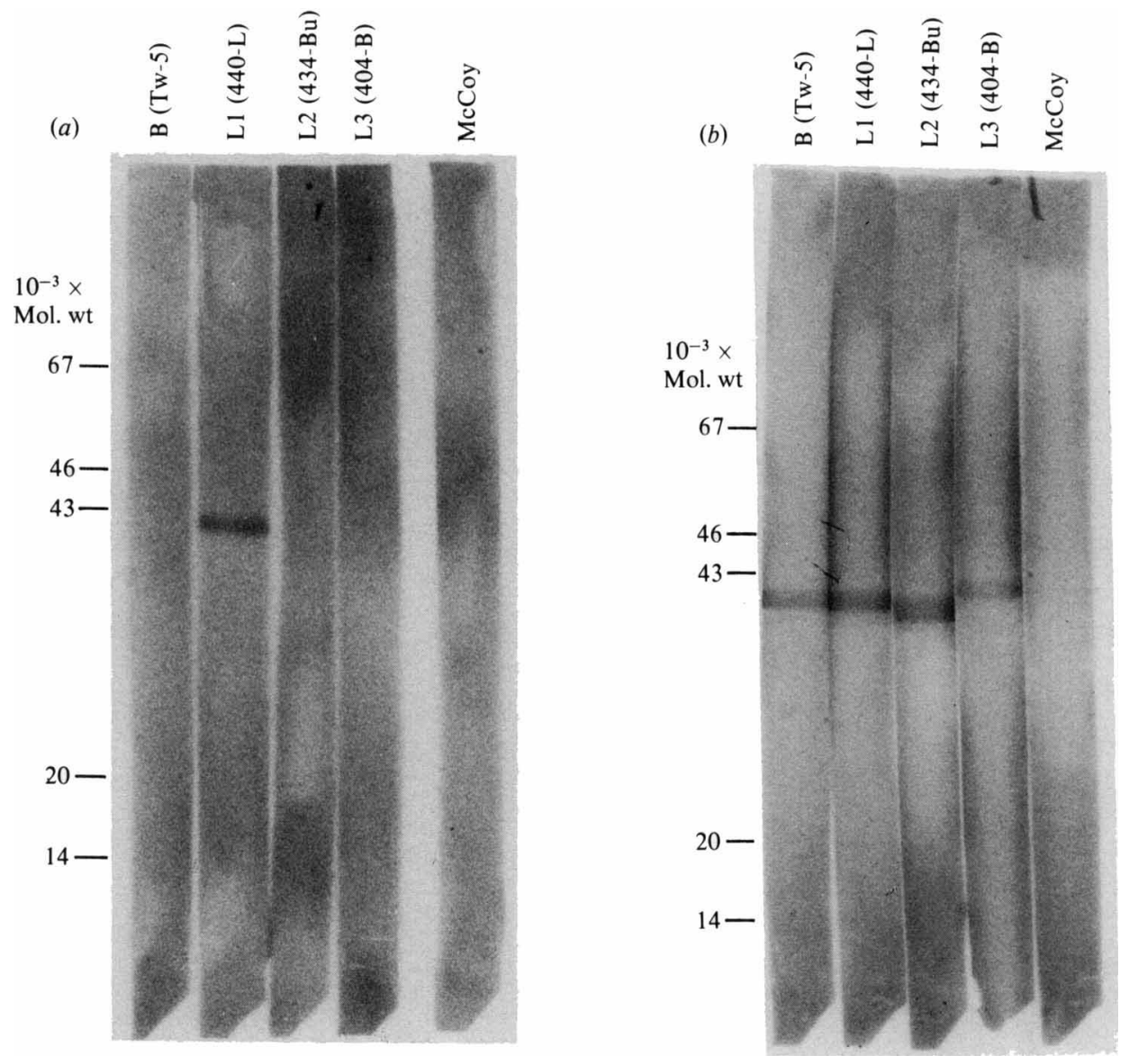

Fig. 2. 'Western blotting' showing C. trachomatis major outer-membrane protein-associated reactivities with $(a)$ type-specific monoclonal antibody $\mathrm{Ll} / \mathrm{B} 5 / \mathrm{H} 4$, and $(b)$ species-specific monoclonal antibody L1/C5/B8.

specific, antibody L1/C5/B8 is $C$. trachomatis species-specific and antibody L2/A11/G3/G4 is genus-specific.

The specificity of monoclonal antibodies against chlamydial polypeptides was tested by 'Western blotting'. The type-specific antibodies L1/A1 (presented earlier; Terho et al., 1982) and L1/B5/H4, only bound to L1 MOMP (Fig. $2 a$ ). L1/C5/B8 species-specific antibody bound to MOMP of all $C$. trachomatis strains tested (Fig. $2 b$ ). Monoclonal antibodies did not bind to McCoy cell proteins.

\section{Epitope analysis of L1-MOMP}

Type-specific inhibition (Table 2). ${ }^{125} \mathrm{I}$-labelled L1/B5/H4 binding was completely inhibited in dilution 1 in 200 by unlabelled L1/B5/H4 antibody, and inhibited $83.3 \%$ by the other typespecific antibody (L1/A1). Species-specific antibody L1/C5/B8 also completely inhibited L1/B5/H4 binding. On the other hand, genus-specific antibody L2/A11/G3/G4 did not significantly inhibit the binding of ${ }^{125} \mathrm{I}$-labelled L1/B5/H4 antibody.

Species-specific inhibition (Table 3). The binding of ${ }^{125}$ I-labelled species-specific L1/C5/B8 antibody was almost completely inhibited by unlabelled homologous antibody, and was only slightly $(4.5 \%)$ inhibited by type-specific L1/A1 antibody; there was $91 \%$ inhibition by typespecific $\mathrm{Ll} / \mathrm{B} 5 / \mathrm{H} 4$ antibody and $18.5 \%$ inhibition by genus-specific antibody L2/A11/G3/G4. 
Table 2. Inhibition of type specificity

Serially diluted non-labelled monoclonal antibodies: type-specific (L1/A1), type-specific (L1/B5/H4), species-specific (L1/C5/B8) and genus-specific (L2/A11/G3/G4) were used to inhibit the binding of ${ }^{125} \mathrm{I}$-labelled type-specific (L1/B5/H4) antibody.

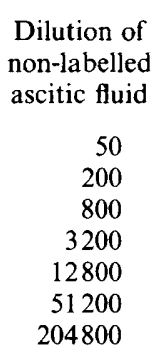

Percentage inhibition of type specificity by non-labelled antibodies

$\begin{array}{rccc}\text { L1/A1 } & \text { L1/B5/H4 } & \text { L1/C5/B } & \text { L2/A11/G3/G4 } \\ 98 \cdot 8 & 100 & 99 \cdot 4 & 16 \cdot 0 \\ 83 \cdot 3 & 100 & 99 \cdot 3 & 7 \cdot 3 \\ 64 \cdot 8 & 96 \cdot 7 & 96 \cdot 6 & 5 \cdot 3 \\ 38 \cdot 1 & 91 \cdot 7 & 82 \cdot 1 & 0 \\ 24 \cdot 9 & 77 \cdot 1 & 29 \cdot 2 & 0 \\ 0 & 28.5 & 0 \cdot 5 & 0 \\ 0 & 2 \cdot 9 & 0 & 0\end{array}$

Table 3. Inhibition of species specificity

Serially diluted non-labelled monoclonal antibodies: type-specific (L1/A1), type-specific (L1/B5/H4), species-specific (L1/C5/B8) and genus-specific (L2/A11/G3/G4) were used to inhibit the binding of ${ }^{125} \mathrm{I}$-labelled species-specific ( $\left.\mathrm{L} 1 / \mathrm{C} 5 / \mathrm{H} 8\right)$ antibody.

Dilution of non-labelled ascitic fluid

50
200
800
3200
12800
51200
204800

\begin{tabular}{|c|c|c|c|}
\hline \multicolumn{4}{|c|}{$\begin{array}{c}\text { Percentage inhibition of species specificity } \\
\text { by non-labelled antibodies }\end{array}$} \\
\hline $\mathrm{L} 1 / \mathrm{Al}$ & $\mathrm{L} 1 / \mathrm{B} 5 / \mathrm{H} 4$ & $\mathrm{L1} / \mathrm{C} 5 / \mathrm{B} 8$ & $\mathrm{~L} 2 / \mathrm{A} 11 / \mathrm{G} 3 / \mathrm{G} 4$ \\
\hline $23 \cdot 8$ & 100 & 100 & $21 \cdot 0$ \\
\hline $4 \cdot 5$ & $91 \cdot 0$ & $92 \cdot 1$ & $18 \cdot 5$ \\
\hline 0 & 77.9 & $62 \cdot 5$ & $7 \cdot 7$ \\
\hline 0 & $66 \cdot 0$ & $58 \cdot 8$ & 0 \\
\hline 0 & $48 \cdot 6$ & $15 \cdot 1$ & 0 \\
\hline 0 & $16 \cdot 0$ & $13 \cdot 3$ & 0 \\
\hline 0 & 11.5 & 0 & 0 \\
\hline
\end{tabular}

\section{Chemical characterization of antigenic epitopes}

$\mathrm{L} 1$ type-specific monoclonal antibodies $\mathrm{L} 1 / \mathrm{A} 1\left(\mathrm{IgG}_{3}\right)$ and $\mathrm{L} 1 / \mathrm{B} 5 / \mathrm{H} 4(\mathrm{IgM})$, C. trachomatis species-specific antibody $\mathrm{L} 1 / \mathrm{C} 5 / \mathrm{B} 8\left(\mathrm{IgG}_{3}\right)$, genus-specific antibody $\mathrm{L} 2 / \mathrm{A} 11 / \mathrm{G} 3 / \mathrm{G} 4\left(\mathrm{IgG}_{3}\right)$ and L1-COMC mouse immune serum were tested against L1-EB antigens. They showed almost equally high titres ( 1 in $10^{6}$ to 1 in $10^{7}$ ) in RIA [Fig. 3(a); hyperimmune serum data not presented].

There was no substantial difference in titre irrespective of whether intact or sonicated antigen was used, but titres with sonicated antigens tended to be somewhat higher. When antigens were heated for $10 \mathrm{~min}$ at $100^{\circ} \mathrm{C}$, all antibodies reacted identically or gave even slighly higher c.p.m. values when compared to control unheated antigens.

The proteolytic effect of proteinase $\mathrm{K}$ (at $100 \mu \mathrm{g} \mathrm{ml}^{-1}$ ) is presented in Fig. 3(b); pronase (at $100 \mu \mathrm{g} \mathrm{ml}^{-1}$ ) had a similar effect. Type and species reactivities were destroyed but genusspecific reactivity was not affected by proteolytic treatment. The reactivity of mouse hyperimmune serum was only slightly diminished when protein antigens were destroyed.

The effect of sodium $m$-periodate treatment is shown in Fig. 3(c). Genus-specific antigen is periodate-sensitive, since this treatment eliminates antibody L2/A11/G3/G4 binding almost completely. $\beta$-Mercaptoethanol did not interfere with any monoclonal antibody reactivity tested. 


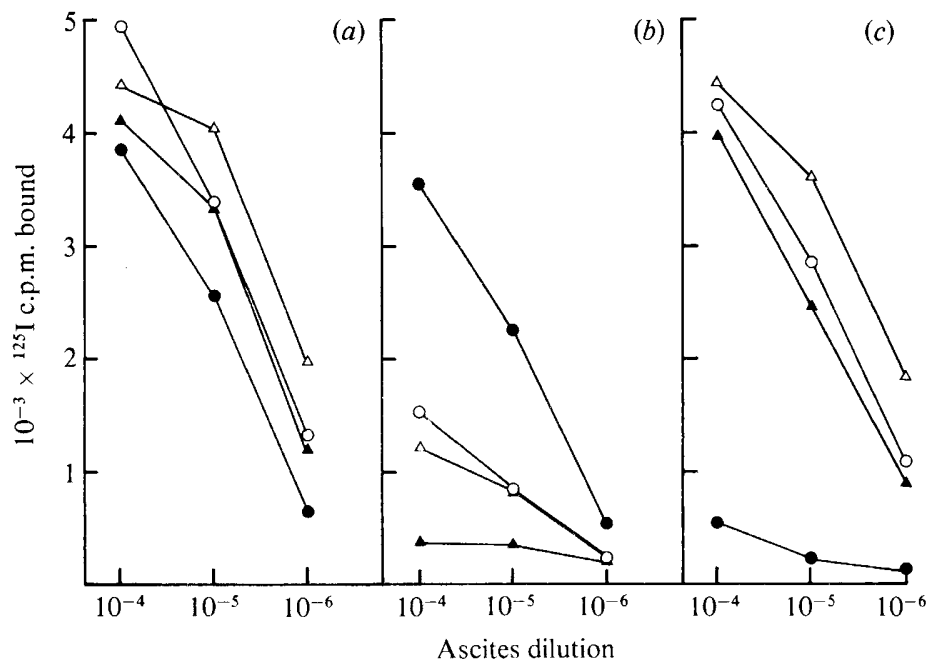

Fig. 3. RIA titration curves for $C$. trachomatis strain L1-EB antigens after chemical treatment: $(a)$ untreated, control antigen; $(b)$ proteinase $\mathrm{K}$-treated $\left(100 \mu \mathrm{g} \mathrm{ml}^{-1}\right)$ antigen; and $(c)$ sodium $m$-periodatetreated $(0.05 \mathrm{M})$ antigen. Monoclonal antibodies with type specificity $\mathrm{Ll} / \mathrm{Al}(\triangle)$ and $\mathrm{L} 1 / \mathrm{B} 5 / \mathrm{H} 4(\mathbf{A})$, with species specificity L1/C5/B8 (O) and with genus specificity L2/A11/G3/G4 (O) were tested against chlamydial membrane.

\section{DISCUSSION}

Using the hybridoma technique of Köhler \& Milstein (1975), several antibody-producing cell lines were chosen by solid-phase ELISA and RIA (Terho \& Matikainen, 1981). Three independent hybrid cell lines that produce monoclonal antibodies against MOMP of $C$. trachomatis type Ll were selected. None of these reacted with uninfected McCoy cells.

The type specificity of antibodies $\mathrm{Ll} / \mathrm{Al}\left(\mathrm{IgG}_{3}\right)$ and $\mathrm{L1} / \mathrm{B} 5 / \mathrm{H} 4(\mathrm{IgM})$ was confirmed by microIF and was shown by electrophoretic blotting after SDS-PAGE to be due to specific reaction with MOMP (mol. wt 40000) (Fig. 2a). This is in contrast with the observations of Stephens et al. (1982) who failed to detect the reaction of type-specific monoclonal antibody with MOMP.

The results of epitope analysis as well as physicochemical characterization of antigenic determinants suggest the existence of two at least partially different epitopes for type specificity in L1-MOMP. These type-specific epitopes were detected by immunoprecipitations after electrophoretic transfer in all available Ll strains tested (440-L, IOL-1962, 810-B); the polypeptide pattern of these strains was identical. The data confirm the specificity of the sophisticated microIF test of Wang \& Grayston (1982). Recently Clark et al. (1982) also demonstrated two different type-specific epitopes on the surface of $C$. trachomatis strain A (HAR-13). They found indirectly by immuno-electron microscopy that two type-specific monoclonal antibodies bound differently on the surface of EB (and reticulate body). Antibody that gave homogeneous binding also mediated full, complement-dependent neutralization, but antibody that bound irregularly did not neutralize under any condition.

MOMP has also been reported to contain determinants of species specificity. Caldwell \& Schachter (1982) isolated MOMPs from $C$. trachomatis and, using them as immunogens, demonstrated species-specific reactivity in mouse serum. Species-specific monoclonal antibodies were also directed against MOMP (Stephens et al., 1982). In our study, MOMPassociated species-specific antibody binding was prevented by the type-specific monoclonal antibody L1/B5/H4 but not by L1/A1. This again indicates the diversity of type-specific epitopes and suggests that type- and species-specific epitopes may share common functional structures or have a close spatial/conformational array. However, the difference in the avidity of monoclonal antibodies employed may partly explain the epitope analysis findings. The avidity 
of monoclonal antibodies is under study in our laboratory. Antibody subclass may also partially explain our data, since the larger inhibitory $\mathrm{IgM}$ antibody $(\mathrm{Ll} / \mathrm{B} 5 / \mathrm{H} 4)$ could sterically prevent the binding of species-specific $\operatorname{IgG}_{3}(\mathrm{~L} / / \mathrm{C} 5 / \mathrm{B} 8)$ more than could the other $\mathrm{IgG}_{3}$ antibody (L1/A1).

In our study, the antigenic determinants for type and species specificity were found to be heatstable, periodate-resistant and $\beta$-mercaptoethanol-resistant; sensitivity to proteolysis demonstrated the protein nature of these antigens (Stephens et al., 1982). Recently it was suggested (Newhall \& Jones, 1982), that monomeric forms of MOMP bound by disulphide bridges may be responsible for structural rigidity. After reduction of inter-chain disulphide bonds the antigenicity was retained (data not shown).

All members of the genus Chlamydia share a common heat-stable antigen that is a lipoprotein-carbohydrate complex (Dhir et al., 1972), containing a periodate-sensitive antigenic determinant. Genus-specific antibody L2/A11/G3/G4 binding was prevented when antigenic determinant was treated by periodate. Genus-specific antigen was not expressed in MOMP when tested by immunoprecipitation after electrophoretic transfer. The partial inhibition of genus-specific antibody may depend on spatial and/or conformational factors, since genus- and species-specific epitopes represent different antigens.

The use of specific monoclonal antibodies has proved valuable in the characterization of chlamydial antigens. These and other monoclonal antibodies will be used for further functional and structural analysis of chlamydial strains.

The expert technical assistance of Ms Tuula Lindholm is gratefully acknowledged. We also express our appreciation to Dr John Treharne, Institute of Ophthalmology, London, U.K., for his expertise on the microIF technique and providing strains of $C$. trachomatis. This work was supported by the $\mathrm{S}$. Juselius Foundation and the Academy of Finland.

\section{REFERENCES}

Caldwell, H. D. \& Schachter, J. (1982). Antigenic analysis of the major outer membrane protein of Chlamydia spp. Infection and Immunity 35, 10241031 .

Caldwell, H. D., Kromhout, J. \& Schachter, J. (1981). Purification and partial characterization of the major outer membrane protein of Chlamydia trachomatis. Infection and Immunity 31, 1161-1176.

Clark, R. B., Nachamkin, I., Schatzki, P. F. \& DALTON, H. P. (1982). Location of distinct surface antigens on Chlamydia trachomatis HAR-13 by immune electron microscopy with monoclonal antibodies. Infection and Immunity 38, 1273-1278.

DhiR, S. P. \& Boatman, E. S. (1972). Location of polysaccharide on Chlamydia psittaci by silvermethenamine staining and electron microscopy. Journal of Bacteriology 111, 267-271.

Dhir, S. P., HaKomori, S., KenNy, G. E. \& Grayston, J. T. (1972). Immunochemical studies on chlamydial group antigen (presence of a 2-keto-3deoxycarbohydrate as immunodominant group). Journal of Immunology 109, 116-122.

HuKKANEN, V. (1982). Lectin reactive components of white matter membranes from normal and multiple sclerosis brains. Journal of Neurochemistry 38, 15371541 .

Hunter, W. M. \& Greenwood, F. C. (1962). Preparation of iodine-131 labelled human growth hormone of high specific activity. Nature, London 194, 495 496.
Köhler, G. \& Milstein, C. (1975). Continuous cultures of fused cells secreting antibody of predefined specificity. Nature, London 256, 495-497.

Newhall, W. J. \& Jones, R. B. (1982). Disulfide mediated cross-linking of the major outer membrane protein of Chlamydia. Abstracts of the XXII Interscience Conference on Antimicrobial Agents and Chemotherapy, p. 147. Washington, D.C.: American Society for Microbiology.

Salari, S. H. \& WARD, M. E. (1981). Polypeptide composition of Chlamydia trachomatis. Journal of General Microbiology 123, 197-207.

SChachteR, J. \& Caldwell, H. D. (1980). Chlamydiae. Annual Review of Microbiology 34, 285309.

Stephens, R. S., TAM, M. R., Kuo, C.-C. \& Nowinski, R. C. (1982). Monoclonal antibodies to Chlamydia trachomatis: antibody specificities and antigen characterization. Journal of Immunology 128, 10831089.

Terho, P. \& Matikainen, M.-T. (1981). Detection of Chlamydia trachomatis antigen by radioimmunoassay. Journal of Immunoassay 2, 239-262.

Terho, P., Matikainen, M.-T., Arstila, P. \& TREHARNE, J. (1982). Monoclonal typespecific antibodies for Chlamydia trachomatis/LGV strains. In Chlamydial Infections, pp. 321-324. Edited by P.-A. Mårdh, K. K. Holmes, J. D. Oriel, P. Piot \& J. Schachter. Amsterdam: Elsevier Biomedical Press. 
Towbin, H., Staehelin, T. \& Gordon, J. (1979). Electrophoretic transfer of proteins from polyacrylamide gels to nitrocellulose sheets: procedure and some applications. Proceedings of the National Academy of Sciences of the United States of America 76, 4350-4354.

Vartio, T., Zardi, L., Balza, E., Towbin, H. \& VAHERI, A. (1982). Monoclonal antibodies in analysis of cathepsin G-digested proteolytic fragments of human plasma fibronectin. Journal of Immunological Methods 55, 309-318.

WanG, S.-P. \& Grayston, J. T. (1982). Micro immunofluorescence antibody responses in Chlamydia trachomatis infection, a review. In Chlamydial Infections, pp. 301-316. Edited by P.-A. Mårdh, K. K. Holmes, J. D. Oriel, P. Piot \& J. Schachter. Amsterdam: Elsevier Biomedical Press. 